\title{
Assessment of climate change impact on pulse, oilseed and vegetable crops at Varanasi, India
}

\author{
M.K. YADAV, R.S. SINGH, K.K. SINGH ${ }^{1}$, R.K. MALL ${ }^{2}$, CHANDRABHAN PATEL, S.K. YADAV ${ }^{3}$ and \\ M.K. SINGH ${ }^{4}$
}

Department of Geophysics, Banaras Hindu University, Varanasi 221005

${ }^{1}$ Agromet Service Cell, India Meteorological Department, New Delhi 110003

${ }^{2}$ Institute of Environment \& Sustainable Development, Banaras Hindu University, Varanasi 221005

${ }^{3}$ Central Potato Research Station, Shillong, Meghalaya 793009

${ }^{4}$ Department of Agronomy, Banaras Hindu University, Varanasi 221005

E-mail:manojagro@gmail.com

\begin{abstract}
Decision Support System for Agrotechnology Transfer (DSSAT v4.6.1) was used to study the impact of climate change and variability on productivity of different monsoon (pigeonpea and groundnut) and winter season crops (chickpea, mustard, tomato and potato) at Varanasi. Keeping in view the observed trends in climate variability, productivity of different cash crops were simulated under plausible synthetic climatic scenarios of changes in temperature and carbon dioxide. Productivity of pigeonpea and groundnut in monsoon season and mustard, tomato and potato in winter season decreased with an increase in temperature. Productivity of different pulse, oilseed and vegetable crops increased under expected enhanced $\mathrm{CO}_{2}$ concentrations. Highest productivity decreased in pigeonpea crop (96.0\%) in monsoon season and minimum in tomato crop (4.0\%) in winter season with an increase of $3.0{ }^{\circ} \mathrm{C}$ in temperature above normal. Highest productivity increase in mustard crop (164.0\%) in winter season and lowest in pigeonpea crop $(33.0 \%)$ in monsoon season were simulated under projected enhanced $\mathrm{CO}_{2}$ concentration of $760 \mathrm{ppm}$. Highest counter-balance in productivity of mustard crop $(150 \%)$ followed by tomato crop $(81 \%)$ during winter season and lowest in pigeonpea crop (99\%) during monsoon season were simulated when an increase in temperature by $3.0^{\circ} \mathrm{C}$ above normal under projected enhanced $\mathrm{CO}_{2}$ concentration of $760 \mathrm{ppm}$.
\end{abstract}

Key words: Pulse, oilseed, vegetable, climate change, DSSAT v4.6.1, Varanasi, India

Pigeonpea and groundnut are important monsoon season crops and chickpea, mustard, tomato and potato are important winter season cash earning crops of Varanasi district. Crop productivity which is highly dependent on climatic changes and variability will need to be maintained at a higher level to meet the future food demands of increasing population. Climatic changes (temperature, radiation, rainfall and carbon dioxide etc.) and variability can affect the yields of different crops; through their direct as well as indirect effects such as weather-induced changes in incidence of insect-pests (Cammell and Knight, 1992), diseases (Fand et $a l ., 2012$ ) and requirement of water and nutrients (Panda $e t$ al., 2003). The direct effects of increased levels of $\mathrm{CO}_{2}$ are generally beneficial to vegetation though global warming and other climatic changes may have a range of negative or positive impacts depending on complex interactions among managed and unmanaged ecosystems (Rosenzweig and Parry, 1994; Long et al., 2006). The past three decades have witnessed globally a rapid increase in the awareness about climatic changes and triggered widespread apprehension amongst scientists and governments about their global implications (Cooper et al., 2009; Byjesh et al., 2010). According to IPCC (2007) the $\mathrm{CO}_{2}$ levels will increase to 605-755 ppm by 2070 and warming of $1.5^{\circ} \mathrm{C}$ by $2015-50$ and $3.0^{\circ} \mathrm{C}$ by $2050-2100$. Recent studies on changes in climate predicted by global climate models (GCMs) suggest that in addition to thermal stress due to global warming, stress on water availability in tropical Asia is likely to be exacerbated in future. In view of futuristic changes in climate, it is imperative to assess their impact on crop productivity for a given region. Simulation techniques are easy, time-saving and economical for studying the influence of climatic variability on growth and yield of the crops. Several such attempts have been made for predicting productivity of different crops under changing climatic conditions (Tubiello et al., 2002, Hundal and Kaur, 2007; 
Gholipoor, 2007, Zacharias et al., 2014; Salack et al., 2015).

\section{MATERIALS AND METHODS}

Taking into account the anticipated regional climatic changes, the effects of changes in temperature and carbon dioxide and it's interaction on yield of different cash crops under Varanasi conditions were studied by using DSSAT v4.6.1 (Hoogenboom et al., 2015). Summary of genetic coefficients of cultivars of different monsoon and winter crops used in simulation are given in Table 1 . The model was calibrated and validated with experimental data of each crop. After validation of model the sensitivity analysis were carried out by changing in input weather parameters. Daily historical weather data at Varanasi $\left(25^{\circ} 18^{\prime}\right.$ North latitude, $83^{\circ} 1^{\prime}$ East longitude and $76 \mathrm{~m}$ altitude) were analysed to determine climatic variability trends by regressing yearly moving average of weather parameters against time. On the basis of climatic variability trends were observed in the district, three plausible synthetic scenarios of change in temperature (maximum and minimum) i.e. 1 . T( $(-3): 3{ }^{\circ} \mathrm{C}$ decrease below normal, 2. $\mathrm{T}(0)$ : normal, $3 . \mathrm{T}(+3): 3{ }^{\circ} \mathrm{C}$ increase above normal and three plausible synthetic scenarios of change in $\mathrm{CO}_{2}$ i.e. 1. $\mathrm{C} 380\left(\mathrm{CO}_{2} 380 \mathrm{ppm}\right.$ - normal), 2. C470 (50\% increase over normal), 3. C760 (100\% increase over normal) and it's interactions (9) were generated for the simulation study. The widely accepted approach to analyse possible effects of different climatic parameters on crop growth and yield by specifying the decremental/incremental changes to temperature and $\mathrm{CO}_{2}$ and applying these changes uniformly to baseline/normal climate was employed in the present study, while taking all the other climate variables to be normal (Yadav et al., 2015). The percent change in productivity was calculated from the normal $\mathrm{T}(\mathrm{O})$ and C-380.

\section{RESULTS AND DISCUSSION}

\section{Effect of temperature change}

When maximum and minimum temperatures were changed by $\pm 3.0^{\circ} \mathrm{C}$ from normal, productivity, anthesis and maturity of pigeonpea and groundnut during monsoon season and chickpea, mustard, tomato, and potato during winter season affected substantially (Table 2). In general, increasing temperature had negative and decreasing temperature had positive impact on productivity of different pulse, oilseed and vegetable crops except chickpea. Phenology of each crop influenced by change in temperature. Similar findings were also reported by
Behboudian and Lai (1994) and Hajarpoor et al.(2014). An increase of $3.0^{\circ} \mathrm{C}$ in temperature above normal increased anthesis by 15 days and maturity by 16 days in pigeonpea, anthesis by 2 days and maturity by 5 days in groundnut and tuber initiation by 8 days in potato. Whereas, an increase of $3.0^{\circ} \mathrm{C}$ in temperature above normal reduced anthesis by 6 days and maturity by 9 days in mustard, anthesis by 0 day and maturity by 12 days in tomato. A shortening of the growth cycle duration is mainly due to the increase in temperature, which accelerates the development phases of different crops. To complete a given phenological stage, a crop needs to accumulate heat (i.e. GDD). Under a warming climate, higher temperatures will result in a more rapid accumulation of GDD and therefore a reduction of some crop development phases and of the crop growth cycles (Salack et al., 2015 ). Highest decrease in productivity of pigeonpea crop (96.0\%) under monsoon season and lowest in tomato crop (4.0\%) during winter season were simulated with an increase of $3.0^{\circ} \mathrm{C}$ in temperature above normal. The productivity of remaining crops decreased by 35.0 per cent in groundnut under monsoon season and by 18.0 per cent in mustard and 19.0 per cent in potato under winter season with an increase in both temperatures i.e. maximum and minimum temperature by $3.0{ }^{\circ} \mathrm{C}$ above normal. High temperature decreases crop production by decreasing photosynthetic function and sugar and starch content, increasing respiration rate, suppressing floral development and hastening crop maturity (Jones, 1992; Abrol and Ingram, 1996). High temperature during reproductive stage causes abnormal development of the male/ female reproductive tissues, poor production of growth regulators in sink tissues, reduced supply of photosynthates, pollen production, pollen viability, fertilization, pod/ fruit/ seed-set/ tuber initiation (potato); all of which lead to poor productivity in pigeonpea (Kesava Rao et al., 2013), groundnut (Prasad et al., 2003; Piara Singh et al., 2014) mustard (Boomiraj et al., 2010; Kumar et al., 2010; Rana et al., 2011), tomato (Moore and Thomas, 1952; Mary et al., 1997; Peet et al., 1998; Ventrella et al., 2012) and potato (Tubiello et al., 2002). In chickpea, increasing temperature had positive and decreasing temperature had negative impact on productivity. Productivity of chickpea crop under winter season increased by 17.0 per cent with an increase in both temperatures by 3.0 ${ }^{\circ} \mathrm{C}$ above normal and decreased by 44.0 per cent with a decrease in both temperatures by $3.0^{\circ} \mathrm{C}$ below normal. Cold stress i.e. temperature fall below $8^{\circ} \mathrm{C}$ (Nayyar and Kumar, 2005) and also heat stress i.e. temperature (maximum/ minimum) rise above $40 / 25^{\circ} \mathrm{C}$ (Devasirvatham et al., 2012) 


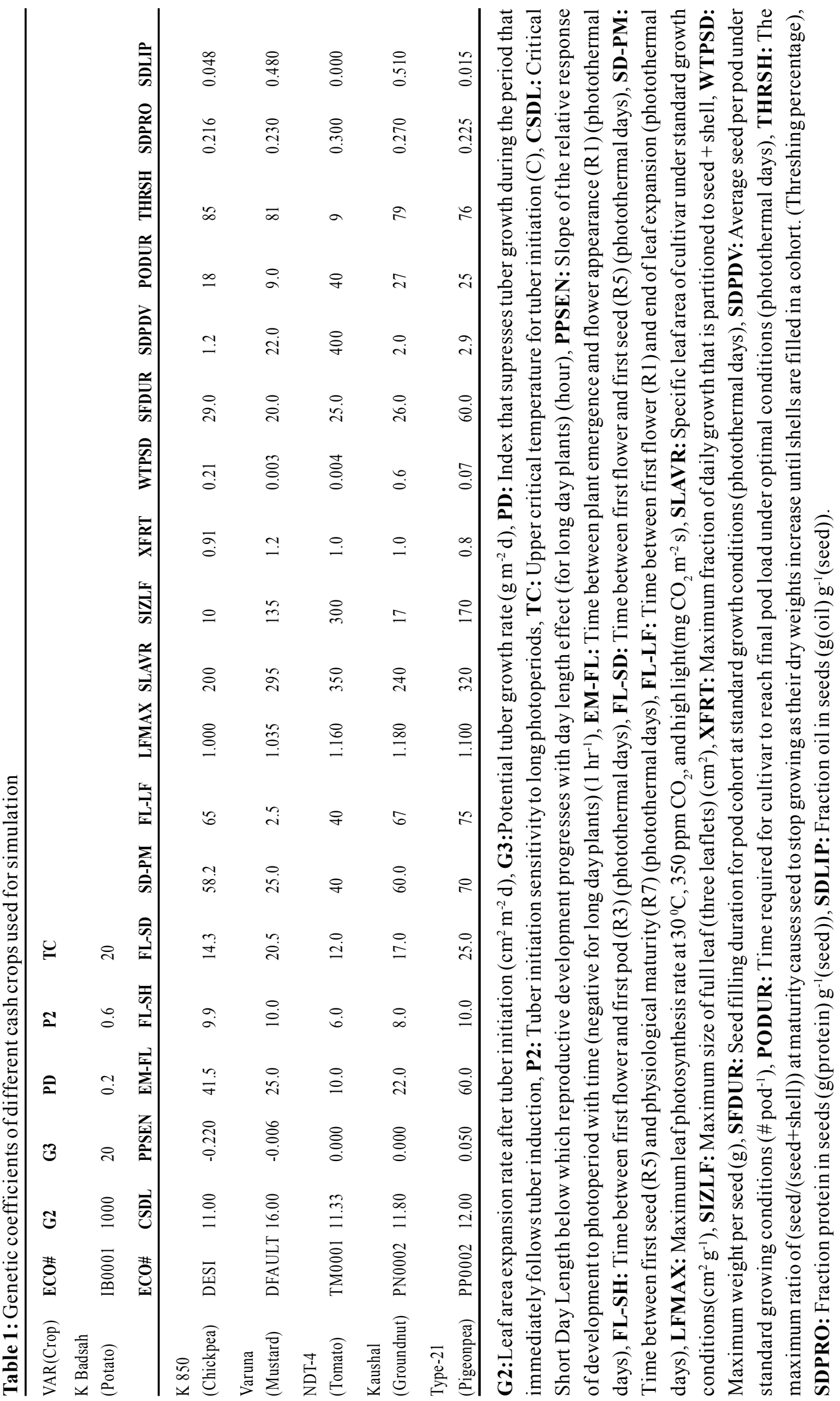




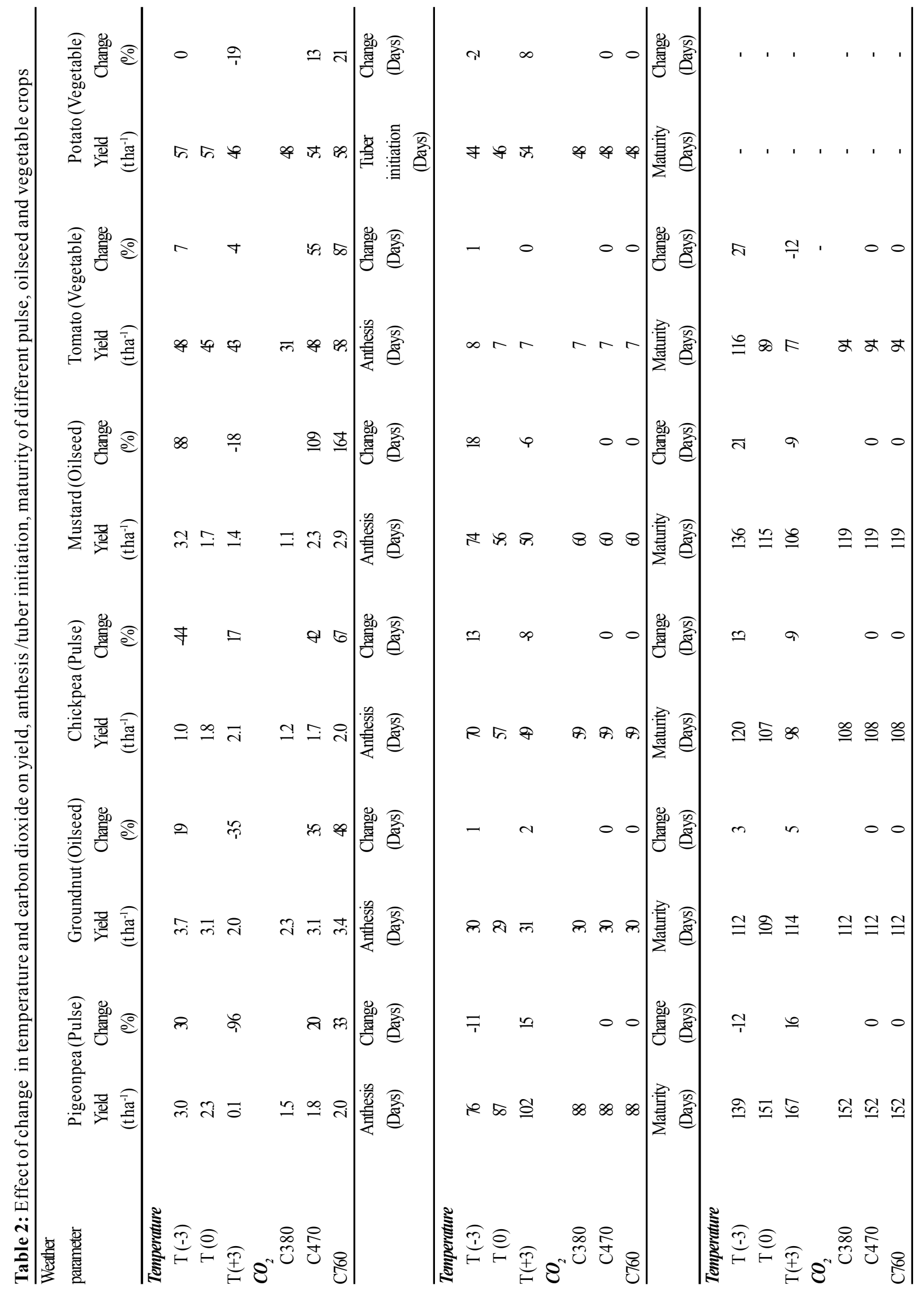


Table 3 (a): Interaction effect of change in temperature and carbon dioxide on yield of different pulse, oilseed and vegetable

\begin{tabular}{|c|c|c|c|c|c|c|c|c|}
\hline \multirow[t]{2}{*}{ Season } & \multirow[t]{2}{*}{ Crop } & \multirow{2}{*}{$\begin{array}{l}\text { Change in } \\
\text { temp. }\end{array}$} & \multicolumn{2}{|c|}{ C380 } & \multicolumn{2}{|c|}{$\mathrm{C} 470$} & \multicolumn{2}{|c|}{ C760 } \\
\hline & & & $\begin{array}{r}\text { Yield } \\
\left(\mathrm{t} \mathrm{ha}^{-1}\right)\end{array}$ & $\begin{array}{r}\text { Change } \\
(\%)\end{array}$ & $\begin{array}{r}\text { Yield } \\
\left(\mathrm{t} \mathrm{ha}^{-1}\right)\end{array}$ & $\begin{array}{r}\text { Change } \\
(\%)\end{array}$ & $\begin{array}{r}\text { Yield } \\
\left(\mathrm{t} \mathrm{ha}^{-1}\right)\end{array}$ & $\begin{array}{r}\text { Change } \\
(\%)\end{array}$ \\
\hline \multirow[t]{6}{*}{ Monsoon } & \multirow{3}{*}{$\begin{array}{l}\text { Pigeonpea } \\
\text { (Pulse) }\end{array}$} & $\mathrm{T}(-3)$ & 2.4 & 33 & 3.1 & 72 & 3.4 & 89 \\
\hline & & $\mathrm{T}(0)$ & 1.8 & - & 2.4 & 33 & 2.7 & 50 \\
\hline & & $\mathrm{T}(+3)$ & 0.2 & -89 & 0.02 & -99 & 0.01 & -99 \\
\hline & \multirow{3}{*}{$\begin{array}{l}\text { Groundnut } \\
\text { (Oilseed) }\end{array}$} & $\mathrm{T}(-3)$ & 2.9 & 16 & 4.0 & 60 & 4.3 & 72 \\
\hline & & $\mathrm{T}(0)$ & 2.5 & - & 3.3 & 32 & 3.6 & 44 \\
\hline & & $\mathrm{T}(+3)$ & 1.5 & -40 & 2.1 & -16 & 2.3 & -8 \\
\hline \multirow[t]{12}{*}{ Winter } & \multirow{3}{*}{$\begin{array}{l}\text { Chickpea } \\
\text { (Pulse) }\end{array}$} & $\mathrm{T}(-3)$ & 0.8 & -38 & 1.0 & -23 & 1.2 & -8 \\
\hline & & $\mathrm{T}(0)$ & 1.3 & - & 1.8 & 38 & 2.2 & 69 \\
\hline & & $\mathrm{T}(+3)$ & 1.6 & 23 & 2.2 & 69 & 2.6 & 100 \\
\hline & \multirow{3}{*}{$\begin{array}{l}\text { Mustard } \\
\text { (Oilseed) }\end{array}$} & $\mathrm{T}(-3)$ & 1.8 & 125 & 3.5 & 338 & 4.2 & 425 \\
\hline & & $\mathrm{T}(0)$ & 0.8 & - & 1.9 & 138 & 2.4 & 200 \\
\hline & & $\mathrm{T}(+3)$ & 0.7 & -13 & 1.5 & 88 & 2.0 & 150 \\
\hline & \multirow{3}{*}{$\begin{array}{l}\text { Tomato } \\
\text { (Vegetable) }\end{array}$} & $\mathrm{T}(-3)$ & 33.9 & 12 & 50.8 & 68 & 60.5 & 100 \\
\hline & & $\mathrm{T}(0)$ & 30.2 & - & 47.2 & 56 & 57.3 & 90 \\
\hline & & $\mathrm{T}(+3)$ & 30.0 & -1 & 45.7 & 51 & 54.7 & 81 \\
\hline & \multirow{3}{*}{$\begin{array}{l}\text { Potato } \\
\text { (Vegetable) }\end{array}$} & $\mathrm{T}(-3)$ & 51.3 & -1 & 57.5 & 11 & 61.7 & 19 \\
\hline & & $\mathrm{T}(0)$ & 51.8 & - & 57.5 & 11 & 61.5 & 19 \\
\hline & & $\mathrm{T}(+3)$ & 40.7 & -21 & 46.4 & -10 & 50.7 & -2 \\
\hline
\end{tabular}

during reproductive growth of chickpea is detrimental to flowering and pod set. Devasirvatham et al. (2012) explained that the high temperatures (40/25) reduced pod set and seed number by reducing pollen viability and pollen production per flower, per cent pollen germination. Singh et al. (2012) observed that temperatures continue to rise from (29/14) in the beginning of March and reaches around 40/25 till the end of April at Varanasi but it could not touch upper limit (40/ 25 ) that detrimental to flowering and pod- set in chickpea even after an increase in both temperatures by $3.0^{\circ} \mathrm{C}$ above normal therefore, detrimental effect of high temperature might not appear on Chickpea crop. However, productivity increase by 19.0 per cent in groundnut and 30.0 per cent in pigeonpea during monsoon season, 88.0 per cent in mustard, 7.0 per cent in tomato during winter season with a decrease in both temperatures by $3.0^{\circ} \mathrm{C}$ below normal.

\section{Effect of carbon dioxide change}

The effect of expected enhanced carbon dioxide change from normal on productivity, anthesis and maturity of different pulse, oilseed and vegetable crops are shown in Table 2. Results of simulation showed that increasing $\mathrm{CO}_{2}$ concentration had no direct effect on anthesis and maturity of different crops. Similar findings also reported by Behboudian and Lai (1994) and Hajarpoor et al.(2014). Productivity of different pulse, oilseed and vegetable crops grown during monsoon and winter season increased under expected enhanced $\mathrm{CO}_{2}$ concentrations. Highest productivity increase in mustard crop $(164.0 \%)$ followed by tomato crop $(87.0 \%)$ under winter season and lowest in potato crop (21.0\%) during winter season was simulated under expected enhanced $\mathrm{CO}_{2}$ concentration of $760 \mathrm{ppm}$. The productivity increased by 20.0 and 33.0 per cent in pigeonpea, by 35.0 and 48.0 per cent in groundnut under monsoon season; by 42.0 and 67.0 per cent in chickpea, by 109.0 and 164.0 per cent in mustard, by 55.0 and 87.0 per cent in tomato and by 13.0 and 21.0 per cent in potato under expected enhanced $\mathrm{CO}_{2}$ concentrations of 470 and 760 ppm, respectively from normal. In $2 \times \mathrm{CO}_{2}$ scenario, grain yield was greater than that of normal simulations; this increase was a result of the improved radiation use efficiency (RUE) and transpiration efficiency (TE) due to increased $\mathrm{CO}_{2}$ concentration. Different crops benefit from elevated $\mathrm{CO}_{2}$ concentrations mainly due to increase in photosynthetic rates. Elevated $\mathrm{CO}_{2}$ generally stimulates leaf-level 
Table 3 (b): Interaction effect of change in temperature and carbon dioxide on anthesis of different pulse, oilseed and vegetable

\begin{tabular}{|c|c|c|c|c|c|c|c|c|}
\hline \multirow[t]{2}{*}{ Season } & \multirow[t]{2}{*}{ Crop } & \multirow{2}{*}{$\begin{array}{l}\text { Change in } \\
\text { temp. }\end{array}$} & \multicolumn{2}{|c|}{$\mathrm{C} 380$} & \multicolumn{2}{|c|}{$\mathrm{C} 470$} & \multicolumn{2}{|c|}{ C760 } \\
\hline & & & $\begin{array}{r}\text { Anthesis } \\
\text { (Days) }\end{array}$ & $\begin{array}{r}\text { Change } \\
\text { (Days) }\end{array}$ & $\begin{array}{r}\text { Anthesis } \\
\text { (Days) }\end{array}$ & $\begin{array}{r}\text { Change } \\
\text { (Days) }\end{array}$ & $\begin{array}{r}\text { Anthesis } \\
\text { (Days) } \\
\end{array}$ & $\begin{array}{r}\text { Change } \\
\text { (Days) }\end{array}$ \\
\hline \multirow[t]{6}{*}{ Monsoon } & Pigeonpea & $\mathrm{T}(-3)$ & 76 & -11 & 76 & -11 & 76 & -11 \\
\hline & (Pulse) & $\mathrm{T}(0)$ & 87 & - & 87 & 0 & 87 & 0 \\
\hline & & $\mathrm{T}(+3)$ & 102 & 15 & 102 & 15 & 102 & 15 \\
\hline & Groundnut & $\mathrm{T}(-3)$ & 30 & 1 & 30 & 1 & 30 & 1 \\
\hline & (Oilsseed) & $\mathrm{T}(0)$ & 29 & - & 29 & 0 & 29 & 0 \\
\hline & & $\mathrm{T}(+3)$ & 31 & 2 & 31 & 2 & 31 & 2 \\
\hline \multirow[t]{12}{*}{ Winter } & Chickpea & $\mathrm{T}(-3)$ & 70 & 13 & 70 & 13 & 70 & 13 \\
\hline & (Pulse) & $\mathrm{T}(0)$ & 57 & - & 57 & 0 & 57 & 0 \\
\hline & & $\mathrm{T}(+3)$ & 49 & -8 & 49 & -8 & 49 & -8 \\
\hline & Mustard & $\mathrm{T}(-3)$ & 74 & 18 & 74 & 18 & 74 & 18 \\
\hline & (Oilseed) & $\mathrm{T}(0)$ & 56 & - & 56 & 0 & 56 & 0 \\
\hline & & $\mathrm{T}(+3)$ & 50 & -6 & 50 & -6 & 50 & -6 \\
\hline & Tomato & $\mathrm{T}(-3)$ & 8 & 1 & 8 & 1 & 8 & 1 \\
\hline & (Vegetable) & $\mathrm{T}(0)$ & 7 & - & 7 & 0 & 7 & 0 \\
\hline & & $\mathrm{T}(+3)$ & 7 & 0 & 7 & 0 & 7 & 0 \\
\hline & Potato & $\mathrm{T}(-3)$ & 44 & -2 & 44 & -2 & 44 & -2 \\
\hline & (Vegetable) & $\mathrm{T}(0)$ & 46 & - & 46 & 0 & 46 & 0 \\
\hline & & $\mathrm{T}(+3)$ & 54 & 8 & 54 & 8 & 54 & 8 \\
\hline
\end{tabular}

photosynthesis, which can be translated into more assimilation and accelerated development. The increasing yield with increase in $\mathrm{CO}_{2}$ level was attributed to greater $\mathrm{LAI}$ and net photosynthetic rates. Results are close conformity with findings of Prasad etal. (2003), Piara Singh et al.(2014), Manpreet Kaur et al. (2013), Zacharias et al. (2014), Saxena and Naresh Kumar (2014) and Dubey et al. (2014).

\section{Interaction effect of temperature and carbon dioxide change}

Productivity, anthesis and maturity of different pulse, oilseed and vegetable crops as affected by change of \pm 3.0 ${ }^{\circ} \mathrm{C}$ in temperature and +190 and $+380 \mathrm{ppm}$ carbon dioxide concentration from normal ( $380 \mathrm{ppm})$ are given in Table 3 (a)-(c). The result of the simulation study shows that there is no interactive effect of change in temperature and $\mathrm{CO}_{2}$ concentration on phenology of different cash crops [Table 3 (b)-(c)]. The effect of combined climate change scenarios on phenology did not differ with increasing $\mathrm{CO}_{2}$ scenarios; this indicated that the fastest crop development was only due to the increase in temperature. Phenology responses to climate change may alter the ability of plants to acquire soil resources (water and nutrients) by altering the timing and duration of the deployment of roots and leaves, which drives resource acquisition. This reduced period happens in a significantlywetter part of the year, sufficient to outweigh the lower radiation levels before and during grain filling. Hajarpoor et al. (2014) in his simulation results showed that doubling $\mathrm{CO}_{2}$ concentration had no direct effect on chickpea phenology but its indirect effect through increasing the temperature reduced days to flowering. They also reported that a faster crop development occurred in chickpea with increase in temperature $\left(\mathrm{T}+2^{\circ} \mathrm{C}, \mathrm{T}+4^{\circ} \mathrm{C}\right.$ and $\left.\mathrm{T}+6^{\circ} \mathrm{C}\right)$, the growing period from sowing to flowering was shortened and maturity dates were occurred earlier. Productivity decreased by 89.0 per cent in pigeonpea, 40.0 per cent in groundnut during monsoon season; 13.0 per cent in mustard, 1.0 per cent in tomato and by 21.0 per cent in potato during winter season from normal when temperature increased by $3.0^{\circ} \mathrm{C}$ above normal at $380 \mathrm{ppm}$ carbon dioxide concentration. Highest counter-balance on productivity of mustard crop $(150 \%)$ of winter season and lowest in pigeonpea crop $(99 \%)$ in monsoon season were simulated when an increase in temperature by $3{ }^{\circ} \mathrm{C}$ above normal under expected enhanced $\mathrm{CO}_{2}$ concentration of $760 \mathrm{ppm}$ [Table 3 (a)]. The 
Table 3 (c): Interaction effect of change in temperature and carbon dioxide on maturity of different pulse, oilseed and vegetable

\begin{tabular}{|c|c|c|c|c|c|c|c|c|}
\hline \multirow[t]{2}{*}{ Season } & \multirow[t]{2}{*}{ Crop } & \multirow{2}{*}{$\begin{array}{l}\text { Change in } \\
\text { temp. }\end{array}$} & \multicolumn{2}{|c|}{ C380 } & \multicolumn{2}{|c|}{$\mathrm{C} 470$} & \multicolumn{2}{|c|}{$\mathrm{C} 760$} \\
\hline & & & $\begin{array}{r}\text { Maturity } \\
\text { (Days) }\end{array}$ & $\begin{array}{r}\text { Change } \\
\text { (Days) }\end{array}$ & $\begin{array}{r}\text { Maturity } \\
\text { (Days) }\end{array}$ & $\begin{array}{r}\text { Change } \\
\text { (Days) }\end{array}$ & $\begin{array}{r}\text { Maturity } \\
\text { (Days) }\end{array}$ & $\begin{array}{r}\text { Change } \\
\text { (Days) }\end{array}$ \\
\hline \multirow[t]{6}{*}{ Monsoon } & \multirow{3}{*}{$\begin{array}{l}\text { Pigeonpea } \\
\text { (Pulse) }\end{array}$} & $\mathrm{T}(-3)$ & 139 & -12 & 139 & -12 & 139 & -12 \\
\hline & & $\mathrm{T}(0)$ & 151 & - & 151 & 0 & 151 & 0 \\
\hline & & $\mathrm{T}(+3)$ & 167 & 16 & 167 & 16 & 167 & 16 \\
\hline & \multirow{3}{*}{$\begin{array}{l}\text { Groundnut } \\
\text { (Oilsseed) }\end{array}$} & $\mathrm{T}(-3)$ & 112 & 3 & 112 & 3 & 112 & 3 \\
\hline & & $\mathrm{T}(0)$ & 109 & - & 109 & 0 & 109 & 0 \\
\hline & & $\mathrm{T}(+3)$ & 114 & 5 & 114 & 5 & 114 & 5 \\
\hline \multirow[t]{12}{*}{ Winter } & \multirow{3}{*}{$\begin{array}{l}\text { Chickpea } \\
\text { (Pulse) }\end{array}$} & $\mathrm{T}(-3)$ & 120 & 13 & 120 & 13 & 120 & 13 \\
\hline & & $\mathrm{T}(0)$ & 107 & - & 107 & 0 & 108 & 1 \\
\hline & & $\mathrm{T}(+3)$ & 98 & -9 & 98 & -9 & 98 & -9 \\
\hline & \multirow{3}{*}{$\begin{array}{l}\text { Mustard } \\
\text { (Oilseed) }\end{array}$} & $\mathrm{T}(-3)$ & 136 & 21 & 136 & 21 & 136 & 21 \\
\hline & & $\mathrm{T}(0)$ & 115 & - & 115 & 0 & 115 & 0 \\
\hline & & $\mathrm{T}(+3)$ & 106 & -9 & 106 & -9 & 106 & -9 \\
\hline & \multirow{3}{*}{$\begin{array}{l}\text { Tomato } \\
\text { (Vegetable) }\end{array}$} & $\mathrm{T}(-3)$ & 116 & 27 & 116 & 27 & 116 & 27 \\
\hline & & $\mathrm{T}(0)$ & 89 & - & 89 & 0 & 89 & 0 \\
\hline & & $\mathrm{T}(+3)$ & 77 & -12 & 77 & -12 & 77 & -12 \\
\hline & \multirow{3}{*}{$\begin{array}{l}\text { Potato } \\
\text { (Vegetable) }\end{array}$} & $\mathrm{T}(-3)$ & - & - & - & - & - & - \\
\hline & & $\mathrm{T}(0)$ & - & - & - & - & - & - \\
\hline & & $\mathrm{T}(+3)$ & - & - & - & - & - & - \\
\hline
\end{tabular}

adverse effect of increase in temperature on productivity of pulse, oilseed and vegetable crops except chickpea were counter-balanced by favourable effect of increasing $\mathrm{CO}_{2}$ levels. Prasad et al. (2003) observed that increasing temperature above $32 / 22^{\circ} \mathrm{C}$ significantly decreased pollen viability and flower, seed and pod-set under ambient (350 ppm) and elevated $\mathrm{CO}_{2}(700 \mathrm{ppm})$ to a similar extent in groundnut. In general, limiting the global mean temperature change of $2{ }^{\circ} \mathrm{C}$, the elevated $\mathrm{CO}_{2}$ concentration showed a positive effect in minimizing the negative impacts of climate change on productivity of tomato (Ventrella et al., 2012). Elevated $\mathrm{CO}_{2}$ generally stimulates leaf-level photosynthesis, which can be translated into more assimilation and accelerated development. However, increase in temperatures likely to offset this benefit due to $\mathrm{CO}_{2}$ or even reduce the yields because cardinal temperatures influences crop physiological process and reproduction, thereby influencing the yields. Results are close conformity with findings of Manpreet Kaur et. al. (2013), Zacharias et al. (2014), Saxena and Naresh Kumar (2014), Piara Singh et al. (2014) and Dubey et al. (2014). Whereas, productivity increased by 89.0 per cent in pigeonpea and 72.0 per cent in groundnut during monsoon season, 425.0 per cent in mustard, 100.0 per cent in tomato and 19 per cent in potato during winter season from normal when temperature decreased by $3.0^{\circ} \mathrm{C}$ below normal under expected enhanced $\mathrm{CO}_{2}$ concentration of $760 \mathrm{ppm}$.

\section{CONCLUSION}

The positive role of carbon dioxide in enhancing photosynthesis and productivity of plant is expected to counteract the negative effects of increase in temperature. Such simulation studies can guide us in determining the effect of climate variability and changes in climate on productivity of different pulse, oilseed and vegetable crops and can be used for crop yield forecasting and further policy planning by government.

\section{REFERENCES}

Abrol, Y.P. and Ingram, K.T. (1996). Effects of higher day and night temperatures on growth and yields of some crop plants. In: Bazzaz F, Sombroek W (eds.) Global climate change and agricultural production. Direct and indirect effects of changing hydrological, pedological and plant 
physiological processes. Wiley, Chichester,pp. 124•140.

Behboudlan, M.H. and Lai, R. (1994). Carbon dioxide enrichment in 'Virosa' tomato plant: Responses to enrichment duration and to temperature. Hort. Sci. 29: 1456-1459.

Boomiraj, K., Chakrabarti, B., Aggarwal, P.K., Choudhary, R. and Chander, S. (2010). Assessing the vulnerability of Indian mustard to climate change. Agric. Ecos. Env., 138(3): 265-273.

Byjesh, K., Kumar, S.N. andAggarwal, P.K. (2010). Simulating impacts, potential adaptation and vulnerability of maize to climate change in India. Mitig. Adapt. Strat. Glob. Chan., 15 (5): 413-431.

Cammell, M.E. and Knight, J.D. (1992). Effects of climatic change on the population dynamics of crop pests. $A d v$. Ecol. Res., 22: 117-162.

Cooper, P., Rao, K.P.C., Singh, P., Dimes, J., Traore, P.S., Rao, K., Dixit, P. and Twomlow, S.J. (2009). Farming with current and future climate risk: Advancing a Hypothesis of Hope for rainfed agriculture in the semi-arid tropics. J. SemiArid Trop. Agric. Res., 7: 1-19.

Devasirvatham, V., Gaur, P.M., Mallikarjuna, N., Tokachichu, R.N., Trethowan, R.M. and Tan, D.K. (2012). Effect of high temperature on the reproductive development of chickpea genotypes under controlled environments. Fun. Plant Biol., 39(12): 1009-1018.

Dubey, S.K., Tripathi, S.K., Pranuthi, G. and Yadav, R. (2014). Impact of projected climate change on wheat varieties in Uttarakhand, India. J. Agrometeorol., 16(1): 26-37.

Fand, B.B., Kamble, A.L. and Kumar, M. (2012). Will climate change pose serious threat to crop pest management: A critical review?. Int.J. Sci. Res. Pub., 2(11): 2250-3153.

Gholipoor, M. (2007). Potential effects of individual versus simultaneous climate change factors on growth and water use in chickpea. Int. J. Plant Prod., 1: 189-204.

Hajarpoor, A., Soltani, A., Zeinali, E., Sayyedi, F. (2014). Simulating climate change impacts on production of chickpea under water-limited conditions. Agric. Sci. Dev., 3(6): 209-217.

Hoogenboom, G., J.W. Jones, P.W. Wilkens, C.H. Porter, K.J. Boote, L.A. Hunt, U. Singh, J.I. Lizaso, J.W. White, O. Uryasev, R. Ogoshi, J. Koo, V. Shelia and G.Y. Tsuji. (2015). Decision Support System for Agrotechnology
Transfer (DSSAT) Version 4.6.1 (www.DSSAT.net). DSSAT Foundation, Prosser, Washington.

Hundal, S.S. and Kaur, P. (2007). Climate variability and its impact on cereal productivity in Indian Punjab. Cur. Sci., 92(4): 506-512.

IPCC (2007). "The physical science basis of climate change-A report of the Intergovernmental Panel on Climate Change. Fourth Assessment report, Summery for policymakers". http://ipcc-wgl.ucar.edu/wgl/wglreport.html.

Jones, H.G. (1992). Plants and microclimate: a quantitative approach to environmental plant physiology, $2^{\text {nd }} e d n$., Cambridge University Press, Cambridge.

Kesava Rao, A.V.R., Wani, S.P., Komuravelly, S., Singh, P., Bairagi, S.D. and Ramadevi, O. (2013). Assessing impacts of projected climate on pigeonpea crop at Gulbarga. $J$. Agrometeorol., 15(Special Issue-II): 32-37.

Kumar, G., Chakravarty, N.V. K., Kurothe, R.S., Sena, D.R., Tripathi, K.P., Adak, T., Haldar, D. andAnuranjan (2010). Effect of projected climate change on mustard (Brassica juncea). J. Agrometeorol., 12(2): 168-173.

Long, S.P., Ainsworth, E.A., Leakey, A.D., Nosberger, J. and Ort, D.R. (2006). Food for thought: lower-than-expected crop yield stimulation with rising $\mathrm{CO}_{2}$ concentrations. Science, 312(5782): 1918-1921.

Manpreet Kour, Singh, K.N., Mahender Singh, Thakur, N.P., Dileep Kachroo and Rohit Sharma (2013). Assessment of climate change and its impact on growth and yield of wheat under temperate and sub-tropical conditions. $J$. Agrometeorol., 15(2): 142-146.

Mary, M. Peet, Willits, D.H. and Gardner, R. (1997). Response of ovule development and post-pollen production processes in male-sterile tomatoes to chronic, sub-acute high temperature stress. J. Exp. Bot., 48(306):101-111.

Moore, E.L. and Thomas, W.O. (1952). Some effects of shading and para-chlorophenoxy acetic acid on fruitfulness of tomatoes. Proc. American Soc. Hort. Sci., 60: 289-94.

Nayyar H, Bains, T. and Kumar, S. (2005). Low temperature induced floral abortion in chickpea: relationship to abscisic acid and cryoprotectants in reproductive organs. Env. Exp. Bot. 53: 39-47.

Panda, R.K., Behera, S.K. and Kashyap, P.S. (2003). Effective management of irrigation water for wheat under stressed conditions. Agric. Water Man., 63(1): 37-56. 
Peet, M.M., Sato, S., and Gardner, R.G. (1998). Comparing heat stress effects on male fertile and male sterile tomatoes. Plant Cell Env., 21(2): 225-231.

Piara Singh, Singh, N.P., Boote, K.J., Nedumaran, S., Srinivas, K. and Bantilan, M.C. (2014). Management options to increase groundnut productivity under climate change at selected sites in India. J. Agrometeorol., 16(1): 52-59.

Prasad, P.V.V., Boote, K.J., Hartwell Allen, L. and Thomas, J.M. (2003). Super optimal temperatures are detrimental to peanut (Arachis hypogaea L.) reproductive processes and yield at both ambient and elevated carbon dioxide. Glob. Chan. Biol., 9(12): 1775-1787.

Rana, R.S., Bhosale, A.B., Sood, R., Sharma, R. and Chande, N. (2011). Simulating impact of climate change on mustard (Brassica juncea) production in Himachal Pradesh. $J$. Agrometeorol., 13(2): 104-109.

Rosenzweig, C. and Parry, M.L. (1994). Potential impact of climate change on world food supply. Nature, 367(6459): 133-138.

Salack, S., Sarr, B., Sangare, S. K., Ly, M., Sanda, I.S. and Kunstmann, H.(2015). Crop-climate ensemble scenarios to improve risk assessment and resilience in the semi-arid regions of West Africa. Clim. Res., 65: 107-121.

Saxena, R. and Naresh Kumar, S. (2014). Simulating the impact of projected climate change on rice (Oryza sativa L.) yield and adaptation strategies in major rice growing regions of India. J. Agrometeorol., 16(1): 18-25.

Singh, R.S., Singh, K.K., Mall, R.K., Yadav, M.K. andGupta, J.P. (2012). Climate of Varanasi.AMFU, DepttofGeophysics, BHU, Varanasi, ISBN: 81-85305-66-8+, DOI: 10.13140/ RG.2.1.1345.0725 p. 22-25.

Tubiello, F.N., Rosenzweig, C., Goldberg, R.A., Jagtap, S. and Jones, J.W. (2002). Effects of climate change on US crop production: simulation results using two different GCM scenarios. Part I: Wheat, potato, maize, and citrus. Clim. Res., 20(3): 259-270.

Ventrella, D., Charfeddine, M., Moriondo, M., Rinaldi, M. and Bindi, M. (2012). Agronomic adaptation strategies under climate change for winter durum wheat and tomato in southern Italy: Irrigation and nitrogen fertilization. Reg. Environ. Chan., 12: 407-419.

Yadav, M.K., Singh, R.S., Singh, K.K., Mall, R.K., Patel, C.B., Yadav, S.K. and Singh, M.K. (2015). Assessment of climate change impact on productivity of different cereal crops in Varanasi, India. J. Agrometeorol., 17(2):179184.

Zacharias, M., Naresh Kumar, S., Singh, S.D., Swaroopa Rani and Aggarwal, P.K. (2014). Assessment of impacts of climate change on rice and wheat in the Indo-Gangetic plains. J. Agrometeorol., 16(1): 9-17. 